\title{
FEEDING PRACTICES IN THE FIRST YEAR OF LIFE
}

\author{
Luciana Galve Alleo', Sonia Buongermino de Souza², Sophia Cornbluth Szarfarc ${ }^{2}$
}

\begin{abstract}
Introduction: Feeding is of particular importance in the first year of life when weaning occurs gradually and competes with complementary feeding to meet the nutritional needs of a child in order to ensure growth and development. Objective: To describe feeding practices in infants in the first year of life. Methods: Cross-sectional study using a questionnaire about a child's eating habits. The sample consisted of 122 children aged up to 365 days, divided into two groups: group 1 consisted of 34 children up to 3 full months of age, and group 2 consisted of 88 children, 4-12 months old. Results: Among the children in group 1, only $35.29 \%$ were exclusively breastfed, but $95.9 \%$ of the study population reported having been breastfed; and $55.68 \%$ of children in group 2 still take milk. In group 2, among the foods already introduced in the infants' feeding was: $83 \%$ fruit, $69 \%$ vegetables, meat broth $52.27 \%, 58 \%$ meat (beef and chicken), $76 \%$ bean broth, $42 \%$ beans, $59 \%$ rice /noodles, $78 \%$ potatoes, $22.72 \%$ egg yolk, $16 \%$ whole egg and $61 \%$ bread wafer. There was no reference to vegetables from $52.27 \%$ of the population, and $73.86 \%$ and $75 \%$ have not introduced fish or liver, respectively. Conclusion: The dietary habits of children who participated in the study include a great diversity of food, but there was a low proportion of exclusive breastfeeding as a result of the early introduction of complementary foods. A low consumption of foods such as vegetables and liver was observed.
\end{abstract}

Key words: breastfeeding, the first year of life, infant feeding.

\section{INTRODUCTION}

According to the World Health Organisation (WHO) adequate nutrition in the first year of life is the practice of exclusive breastfeeding up to six months of age, but from this age on, the child should start complementary feeding and continue getting breast milk up to two years of age ${ }^{1}$.

Insufficient and/or inadequate nutrition is recognised as the main determinant of child malnutrition. Adequate nutrition is essential especially during childhood, as a premise to ensure proper growth and development of children. The practice of a balanced diet and healthy eating habits from childhood provide optimal levels of health, and promote physical and intellectual development, thus reducing the risk of disorders caused by common nutritional deficiencies in this stage of development, and also preventing the manifestation of obesity ${ }^{2-5}$.

The combination of exclusive breastfeeding up to six months and healthy eating habits during complementary feeding-with the introduction of the food groups in a comprehensive mannersignificantly reduces child mortality in this period, in addition to providing an adequate supply of nutrients for the child 3,6 .

To ensure that the recommendations established by WHO are followed correctly, the Brazilian government established ten steps to healthy eating, the "Food Guide for Children under Two Years." This was intended for primary health care, to help guide mothers in this phase that is so important in a child's life. The guide reinforces all the above behaviours related to exclusive breastfeeding and complementary feeding stages, and provides guidelines for cleaning and food conservation ${ }^{4}$.

Accumulating evidence in recent years that a health system based on primary care achieves better outcomes for public health along with individualised attention, made it beneficial; and it is in the process of implementation by the Family Health Programme, now called the Family Health Strategy (FHS). Created in 1993, this programme proposed the restructuring of the health system

1 Nutritionist, Master in sciences, by graduate programme in public health nutrition the School of Public Health, University of São Paulo (USP) Brazil.

2 Professor Associate - Department of Nutrition, School of Public Health - USP.

This article is based on the master's degree dissertation - Luciana Galve Alleo entitled: "Prevalence of anemia and relationship between the concentration of hemoglobin in mothers and children enrolled in Basic Health Units of Santa Isabel" held in September of 2013. Available in: http://www.teses.usp.br/teses/disponiveis/6/6138/tde-25092013-155119/en.php Acknowledgments: We acknowledge the financial assistance provided by CNPQ (National Council for Scientific and Technological Development) and CAPES (Coordination of Improvement of Higher Education Personnel).

Corresponding author: luciana.alleo@usp.br

Suggested citation: Alleo LG, Souza SB, Szarfarc SC. Feeding practices in the first year of life, Journal of Human Growth and Development, 24(2): 195-200

Manuscript submitted Oct 08 2013, accepted for publication Feb 222014. 
in the country, to organise primary care and replace existing traditional models, focusing on disease surveillance. Currently, the FHS programme is consolidated as the first level of health care in the National Health System (NHS), expanding access to and services as close as possible to each Brazilian family?.

The objective is to describe the feeding practices in infants in the first year of life.

\section{METHODS}

This is a cross-sectional study that applied a qualitative questionnaire on the eating habits of children, and obtained information for the characterisation of the sample.

The sample consisted of 122 children who attended the Basic Health Units (BHU) for well child visits during the period 25 July to 13 September 2012 in the municipality of Santa Isabel in the state of São Paulo.

In order to test the questionnaires regarding food intake and assessment of socioeconomic and demographic factors, the study was preceded by its participation in a pilot study conducted at the School Health Center Geraldo de Paula Souza, School of Public Health, University of Sao Paulo.

All children participating in the study were aged up to 365 days and were divided into two groups: group 1 with 34 children up to three full months of age, and group 2 comprised of 88 children aged 4-12 months.

Regarding feeding practices in the first year of life of the child, we examined the types of milk intake by age, from birth to 11 months and for 30 days. We also checked the consumption of other foods featuring complementary feeding for these children.

The results are descriptive and presented in numbers and proportions.

The study was approved by the Faculty of Public Health, University of São Paulo Research Ethics Committee (REC), Protocol ( $N^{\circ} 2340$ ).

\section{RESULTS}

About $6,5 \%$ women could not inform about the family income. At the same time draws the attention high proportion $(71,4 \%)$ of them with schooling above the elementary level, with 9 or more classes approved.

Table 1: Demographic and socioeconomic characteristics of 122 mothers and children who participated in the study. Santa Isabel/SP 2012.

\begin{tabular}{|c|c|c|}
\hline VARIABLES & No & $\%$ \\
\hline \multicolumn{3}{|l|}{ Age of children (months) } \\
\hline $0-3$ & 34 & 27,87 \\
\hline $4-5$ & 34 & 27,87 \\
\hline $6-11$ & 54 & 44,26 \\
\hline \multicolumn{3}{|l|}{ Sex of child } \\
\hline Male & 66 & 54,10 \\
\hline Female & 56 & 45,90 \\
\hline \multicolumn{3}{|c|}{ Maternal scholing (years of study) } \\
\hline $3-4$ & 6 & 4,92 \\
\hline $5-8$ & 29 & 23,77 \\
\hline $9 \mathrm{e}+$ & 87 & 71,31 \\
\hline \multicolumn{3}{|l|}{ Maternal employment } \\
\hline Yes & 41 & 33,61 \\
\hline No & 81 & 66,39 \\
\hline \multicolumn{3}{|l|}{ Head of family } \\
\hline Father & 65 & 53,28 \\
\hline Mother & 8 & 6,56 \\
\hline Other & 49 & 40,16 \\
\hline \multicolumn{3}{|l|}{ Family income (minimun wage)* } \\
\hline$<1$ & 14 & 11,48 \\
\hline $1-2$ & 50 & 40,98 \\
\hline 3 ou + & 50 & 40,98 \\
\hline \multicolumn{3}{|l|}{ Number of people in residence } \\
\hline $2-3$ & 46 & 37,70 \\
\hline $4 e+$ & 76 & 62,30 \\
\hline \multicolumn{3}{|l|}{ Point of care } \\
\hline FHS & 98 & 80,33 \\
\hline $\mathrm{BHU}$ traditional & 24 & 19,67 \\
\hline Total number of children & 122 & 100 \\
\hline
\end{tabular}


Table 2: Distribution of children by number and percentage second intake of milk and age. Santa Isabel / SP 2012.

$\left.\begin{array}{cccccc}\begin{array}{c}\mathbf{N}^{\circ} \text { of } \\ \text { children }\end{array} & \begin{array}{c}\text { Age in } \\ \text { months } \\ \mathbf{n}^{\circ}(\%)\end{array} & \begin{array}{c}\text { Exclusive } \\ \text { Breast milk } \\ \mathbf{n}^{\circ}(\%)\end{array} & \begin{array}{c}\text { Breast milk } \\ + \text { not milk } \\ \mathbf{n}^{\circ}(\%)\end{array} & \begin{array}{c}\text { Breast milk } \\ \text { Cow's milk } \\ (\%)\end{array} & \begin{array}{c}\text { Cow's } \\ \text { milk }\end{array} \\ \mathbf{n}^{\circ}(\%)\end{array}\right)$

Fruits tended to be the first non-dairy food, but cow's milk was often the food of choice for weaning. As can be seen, 70\% of children had cow's milk in their diet, and along with it, thickening and/ or sugars. Among the group of 122 children, 104 $(85.3 \%)$ had started complementary feeding.
Among the children in group 1 , only $35.29 \%$ were exclusively breastfeeding, but $95.9 \%$ of the study population reported having been breastfed, and $55.68 \%$ of children in group 2 were still taking breast milk.

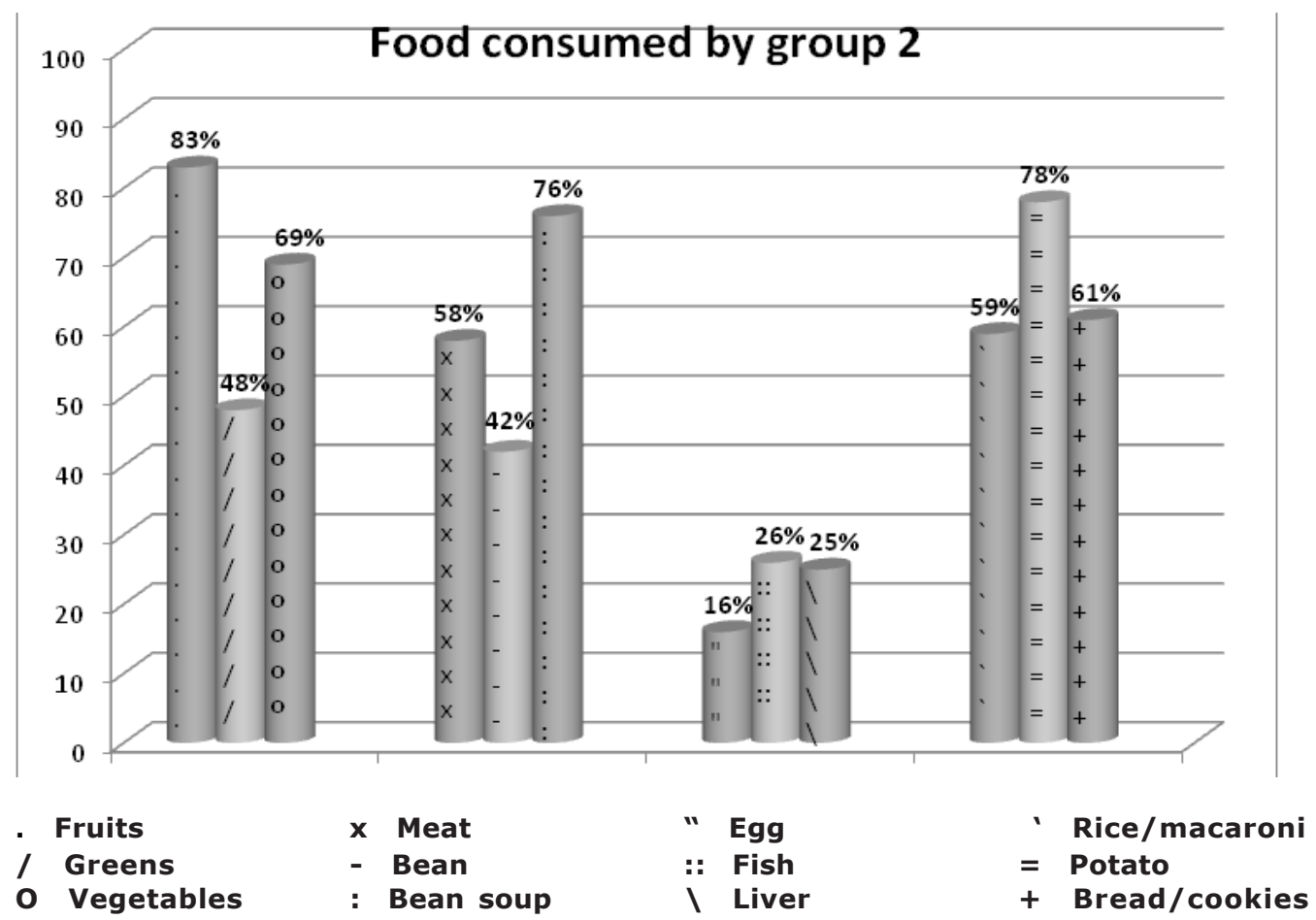

Figure 1: Foods such as entering the supply of child 4 to 12 months( $N=88$, group). Santa Isabel /SP 2012.

Table 3: Distribution of mothers second participation in nutrition education activities in BHU. Santa Isabel/SP 2012

$\begin{array}{ccc}\text { Nutrition education } & \text { No } & \% \\ \text { Yes } & 12 & 9,84 \\ \text { No } & 110 & 90,16 \\ \text { Total } & 122 & 100\end{array}$

\section{DISCUSSION}

Different from what occurs among Brazilian women, especially those seen in $\mathrm{BHU}$ the majority (71\%) of mothers completed and/or passed primary school. About two-thirds of these mothers do not work. It is noteworthy, though, that there was a large number of families in which the head of the household is not the father or mother, but grandparents, and there was even the occurrence of sharing between relatives and there is even the share of the management and household expenses among several residents 8,9. In relation to breastfeeding, Table 2 shows that the studied population in Santa Isabel is far from meeting the WHO recommendations 
regarding exclusive breastfeeding up to six months. Even among the 34 children younger than four months old, exclusive breastfeeding appears in a small proportion.

Studies show that for the same segment, exclusive breastfeeding ensures proper growth in the first six months of life, and that apparent changes in the growth of children in this context should be evaluated carefully in order to avoid the introduction of unnecessary complementary feeding ${ }^{10}$

There are several studies in different regions of Brazil that showed that exclusive breastfeeding is maintained for an insufficient period of time, given the early introduction of complementary feeding ${ }^{11-15}$

From these observations, as well as from observations in this study, some authors highlight the importance of food/nutritional guidance, and the need for FHS teams of BHU to reinforce the recommendations in the guidelines established by WHO and Ministry of Health $(\mathrm{MH})^{13,15-17}$.

Although the feed is currently oriented to contain all food groups, encouraging the family feed supplied to the child from the early introduction of complementary foods, with change only in texture, it is noted that the traditional way of introducing food is maintained. Fruits and vegetables appear as the most common foods, followed by bean broth and meat.

It should also be noted that although all food groups were present at the end of the study period, the amount provided of each one is different. Meat, bread, and biscuits are offered in small amounts. Also, there was almost no variety in meats, and was restricted to beef and chicken.

Bean soup, already offered in early childhood, does not contain the amount of nutrients from the grains that are a source of iron and protein. The exclusive use of bean broth in infant feeding is a national habit that has been already evidenced by a similar study that found that among $70.4 \%$ of children aged 6-12 months, there was an absence of grain in the habitual $\operatorname{diet}^{18}$.

Intake of vegetables, liver, and fish is infrequent in infant feeding, which may compromise the supply of fiber and some micronutrients. A healthy diet should include diverse enough foods to ensure the contribution of all the needed amounts of macro and micronutrients. Some studies show as well that children in this age group consume insufficient quantities to meet the nutritional recommendations ${ }^{15}$

Knowing the nutritional recommendations and appropriate feeding practices, it can be inferred that both the natural food sources of iron-meat and bean grains-and mineral-fortified food such as bread, mush, biscuits and others prepared with wheat flour and corn, are ingested in small amounts. In addition, among infants, milk, which occupies a very important position in the supply of calories and iron-rich foods, ends up being consumed insufficiently.
The significant increase in the intake of processed foods, which are high in fats, sugar, and low in specific nutrients, increases the risk of overweight and obesity that is occurring with increasing frequency in Brazil due to the nutritional transition. Overweight and childhood obesity are possibly related to the early introduction of complementary foods associated with weaning prematurely ${ }^{19-20}$.

A similar study ${ }^{14}$ evaluated the practices and dietary intake of healthy infants in three Brazilian cities, and highlighted the high percentage of children in the first year of life that already consumed whole cow's milk in their diet. There is evidence in studies showing that this dietary practice increases by twice the risk of obesity compared to children who breastfeed as the only source of milk $21-22$.

Thus, the studies showed low adherence to exclusive breastfeeding in the first half of life as a result of the early introduction of complementary foods, low intake of vegetables, and low consumption of foods fortified with iron and natural sources.

This research highlights the need for programmes with nutrition education activities. They should be guided by qualified professionals who work with mothers attending basic health units from pregnancy to two years of a child's life.

$A$ recent study evaluated the effectiveness of nutritional counseling for infants regarding the introduction of complementary foods, and examined the association of dietary habits with age and maternal education. The authors found no relationship between the presence of the food groups in the habitual diet with age and maternal education ${ }^{23}$. A second study conducted in Feira de Santana in Bahia also showed no association between the level of maternal education and the introduction of a family meal in the feeding of children up to age four months ${ }^{24}$. Nutritional counseling over time proved effective, resulting in the qualitative improvement of complementary feeding, regardless of the age factor and maternal education. This reinforces the importance of dietary guidance in this important stage of life ${ }^{23}$.

Low income may also be considered a limitation found in this study because it can be considered a variable that hampers the population from having a diet with greater diversity of foods, especially fruits and vegetables.

The influence of income and food prices in relation to the participation of fruit and vegetables in household food consumption was analysed in a survey published in 2007. The data used were based on the Household Budget Survey of the Institute of 1998/99 Economic Research, in São Paulo. It was concluded that a reduction in the price of fruits and vegetables, which can be obtained by public policies, could increase the inclusion of these foods in the diet of families in the municipality of São Paulo. The same is possibly occurring in Santa Isabel. Because, as previously seen in Table 1, most of the population lives with one to two minimum wage-earners, and certainly this low-income constraint is responsible for the consumption of fruits and vegetables ${ }^{25}$. 
In conclusion, the eating habits of children include a diverse supply of food because of the early introduction of complementary foods, and because of a low consumption of foods such as vegetables and liver-food sources of iron-but there is a low proportion of exclusive breastfeeding.

\section{Acknowledgments}

We acknowledge the financial assistance provided by CNPQ (National Council for Scientific and Technological Development) and CAPES (Coordination of Improvement of Higher Education Personnel).

\section{REFERENCES}

1. WHO - World Health Organization. Indicators for assessing breastfeeding practices. Reprinted report of an Informal Meeting, 1112 June, Geneva, 1991. WHO/CDD/SER/ 91.14. Pgs 3-6.

https://extranet.who.int/iris/restricted/ b i t strea m/10665/62134/1/ WHO_CDD_SER_91.14.pdf.

2. Figueiredo ICR, Jaime PC, Monteiro CA. Factors associated with the consumption of fruits and vegetables among adults in the city of São Paulo. Rev. Public Health. 2008; 42 (5): 777-85

http://www.scielo.br/pdf/csp/v27n2/12.pdf.

3. Garcia MT, Granado FS, Cardoso MA. Complementary feeding and nutritional status of children under two years attended the Family Health Program in Acre, Western Brazilian Amazon. Bull World Health Organ. 2011; 27 (2):305-16.

http://www.scielosp.org/pdf/csp/v27n2/ 12.pdf.

4. Ministry of Health, Department of Health Care of the Department of Primary Care. Ten steps to healthy eating: food guide for children under two years: a guide for health professionals in primary care. Brazilia, 2nd ed. (Series A, Standards and Technical Manuals), DF, 2010:7-15.

http://189.28.128.100/nutricao/docs/geral/ enpacs10passos.pdf.

5. Spinelli MGN, Goulart RMM, Santos ALP, Gumiero LC, Farhud CC et al. Food intake of children aged 6 to 18 months in daycare. Rev. Nutr. 2003, 16 ( 4):409 -14.

http://www.scielo.br/pdf/rn/v16n4/ a04v16n4.pdf.

6. Cocco RR, Souza FS, Sarni RO, Mallozi MC, Solé $D$. The role of nutrition in the first year of life on the prevention of allergic diseases. Rev. Bras. Alle. Imunopatol. 2009, 32 (2):68 -71. http://www.asbai.org.br/revistas/Vol322/ A R T \% $202-09 \% 20-\% 20$ th e \% $200 \% 20$ papel\%20nutri\%C3\%A7\%C3\% A3o.pdf.

7. Ministry of Health; Memories of Family Health in Brazil. Department of Health Care Department of Primary Care: Brasilia DF, 2010. P 9-40.

http://bvsms.saude.gov.br/bvs/publicacoes/ memorias_saude_familia_brasil.pdf.
8. Ministry of Health, Brazilian Center for Analysis and Planning. National Demographic and Health of Children and Women's - 2006 PNDS: dimensions of the reproductive process and child health. Brasilia: Ministry of Health 2009 - Cunha EMGP. Sociodemographic characteristics of Brazilian women, Chapter 3: 55-67.

http://bvsms.saude.gov.br/bvs/publicacoes/ pnds_crianca_mulher.pdf.

9. Frota MTBA. Prevalence and factors associated with anemia in women and children in Maranhão factors. [Doctoral Thesis]. School of Public Health School, 2013: 44.

www.teses.usp.br/teses/disponiveis/6/ 6138/...08042013.../TerezaFrota.pdf.

10. Augusto RA, Souza JMP. Growth of infants exclusively breastfed in the first six months of life. Rev Bras Growth DEVELOPMENT Hum 2007; 17 (2):01-11. www.revistas.usp.br/ jhgd/article/download/19827/21899.

11. Parada CMGL, Carvalhaes MABL, Jamas MT. Complementary feeding practices in children in the first year of life. Rev Latino-am Nursing March-April 2007, 15(2).

http://www.scielo.br/pdf/rlae/v15n2/ pt_v15n2a14.pdf.

12. Simon VGN, Souza JMP, Souza SB. Introduction of complementary foods and their relationship with demographic and socioeconomic variables in children in the first year of life, born in a University Hospital in São Paulo. Rev. Bras. Epidemiol. Vol.6, No 1, 2003.

http://www.scielosp.org/pdf/rbepid/v6n1/ 05.pdf.

13. Bernardi JLD, Jordan RE, Filho AAB. Complementary feeding of infants in a city developed in the context of a developing country. Rev Panam Salud Publica/ Pan Am J Public Health 26 (5), 2009.

http://www.scielosp.org/pdf/rpsp/v26n5/ 04.pdf.

14. Caetano MC, Ortiz TTO, Silva SGL, Souza FIS, Sarni ROS. Complementary feeding: inappropriate practices in infants. Arch Pediatr Urug 2012, 83 (3): 226-32. DOI:10.2223/ JPED. 1994.

15. Oliveira LPM, Assis AMO, Pinheiro SMC, Prado MS, Barreto ML. Complementary feeding in the first two years of life. Rev. Nutr., Campinas, 2005, 18 (4):459-69. 
http://www.scielo.br/pdf/rn/v18n4/ 25844.pdf.

16. Giugliani ERJ, Victora CG. Complementary feeding. J. Pediatr. 2000:76 (Supl3): 253-62. http://www.lume.ufrgs.br/bitstream/handle/ 10183/54367/000295650.pdf?sequence $=1$.

17. Monte CMG, Giugliani ERJ. Recommendations for complementary feeding of the breastfed child. J Pediatr. 2004; 80 (5 Suppl):131-41. http://www.scielo.br/pdf/jped/v80n5s0/ v80n5s0a04.pdf.

18. Assis AMO, Gaudenzi EN, Gomes G, Ribeiro RC, Szarfarc SC, Souza SB. Hemoglobin levels, breastfeeding and complementary feeding in the first year of life. Rev. Public Health. 2004:38 (4):543-51.

http://www.scielo.br/pdf/rsp/v38n4/ 21084.pdf.

19. Araújo MFM, Beserra EP, Chaves ES. The role of ineffective breastfeeding on child obesity: an aspect for nursing research. Acta Paul Enferm 2006; 19 (4):450-5.

http://www.scielo.br/pdf/ape/v19n4/v19 n4a14.pdf.

20. Soares LD, Petroski EL. Prevalence, etiological factors and treatment of childhood obesity. Rev. Bras. of Scholarly \& Human Performance. ISSN 1980-0037. Vol 5, 2003; in (1): 63-74.

LDSoares, ELPetroski-BrazilianJournalof Scholarly...,2003-researchgate.net.
21. Siqueira RS, Monteiro CA. Breastfeeding and obesity in school- age children from families of high socioeconomic status. Rev Public Health 2007, 41 (1):5-12.

http://www.scielo.br/pdf/rsp/v41n1/03.pdf.

22. Simon VGN, Souza JMP, Souza SB. Breastfeeding, complementary feeding, overweight and obesity in preschool children. Rev Public Health 2009, 43 (1):60-9.

http://www.scielo.br/pdf/rsp/v43n1/ 6990.pdf.

23. Torigoe CY, Asakura L, Sachs A, Silva CVD, Abrão ACFV, Santos GMS, Coelho LC. Influence of nutritional counseling on complementary feeding practices in infants. Journal of Human Growth and Development 2012, 22 (1): 1-11. www.revistas.usp.br/jhgd/article/download/ 20055/22169.

24. Vieira GO, Silva LR, Vieira TO, Almeida JAG, Cabral VA. Eating habits of children under 1 year breastfed and non-breastfed. J Pediatr (RioJ). 2004, 80 (5):411-6.

http://www.scielo.br/pdf/jped/v80n5/v80n 5a13.pdf.

25. Claro RM, Carmo HCE, Machado FMS, Monteiro CA. Income, food prices and participation of fruit and vegetables in the diet. Rev Public Health 2007, 41 (4):557-64.

http://www.scielo.br/pdf/rsp/v41n4/ 6285.pdf. 